\title{
Where Do we Go from here
}

\section{Albert DA*}

Department of Medicine, of Pediatrics and of The Dartmouth Institute, Rheumatology Division, Dartmouth-Hitchcock Medical Center

*Corresponding author: Albert DA, Professor of Medicine, of Pediatrics and of The Dartmouth Institute, Rheumatology Division, Dartmouth-Hitchcock Medical Center, Tel: 603-650-4988; E-mail: Daniel.A.Albert@Hitchcock.org

Received date: September 01, 2015; Accepted date: September 03, 2015; Published date: September 06, 2015

Copyright: $\odot 2015$ Albert DA. This is an open-access article distributed under the terms of the Creative Commons Attribution License, which permits unrestricted use, distribution, and reproduction in any medium, provided the original author and source are credited.

\section{Editorial}

We have made enormous progress in the management of patients with systemic vasculitis. Just remember when the only option for patients with Wegener's Granulomatosus as we used to call GPA was cyclophosphamide and how surprised we were that Rituximab was so effective [1,2]. Or when the cure of patients with mixed cryoglobulinemia was a dream. Now the association with Hepatitis $\mathrm{C}$ is confirmed and we have witnessed the dramatic cure of patients with decades of disease using newer antivirals [3].

Unfortunately, these are isolated victories in a war that we are just beginning to fight. For Giant Cell Arteritis and its non arteritic companion polymyalgia rheumatica we are just beginning to develop steroid sparing therapy. In the younger version of large vessel vasculitis Takayasu we also do not know what second line drug to use or even how to measure disease activity. In childhood Henoch Schonlein Purpura we don't know which patients need corticosteroids and which ones will resolve without them. In the adult form of HSP we don't have a clear cut steroid sparing regimen. The list goes on and on. These are tough nuts to crack and even if we were to discern etiologic agents the most likely scenario is that they will interact with a particular genetic predisposition to respond with vascular inflammation. An example of this is the role of varicella zoster virus in Giant Cell Arteritis. There is emerging data that this agent that typically causes chicken pox and later shingles can be associated with a vasculitis and even more recent data that GCA biopsies can stain positive for VZV antigen unlike atherosclerotic vessels [4].
In short there are numerous questions to be asked many of which will require resources from multiple institutions through the beautifully developed collaborations which were largely cobbled together by the senior leaders in our field. We need to recognize acknowledge and thank them for doing the hard work that will permit us to move forward again a very difficult set of disorders that result in serious, often life threatening, disease. It is time to redouble our efforts and push the envelope forward. Hopefully much of the advances will be told in the papers published in this journal which will be solely devoted to the field of vasculitis. It will be an exciting time for everyone involved in vasculitis care and research.

\section{References}

1. Stone JH, Merkel PA, Spiera R, Seo P, Langford CA, et al. (2010) Rituximab versus Cyclophosphamide for ANCA-Associated Vasculitis. N Engl J Med 363: 221-232.

2. Jones RB, Furuta S, Tervaert JW, Hauser T, Luqmani R, et al. (2015) Rituximab versus cyclophosphamide in ANCA-associated renal vasculitis: 2-year results of a randomized trial. Ann Rheum Dis 74: 1178-1182.

3. Gragnani L, Fabbrizzi A, Triboli E, Urraro T, Boldrini B, et al. (2014) Triple antiviral therapy in hepatitis $C$ virus infection with or without mixed cryoglobulinemia: A prospective, controlled pilot study. Dig Liver Dis 46: 833-837.

4. Gilden D, Nagel M (2015) Varicella zoster virus in temporal arteries of patients with giant cell arteritis. J Infect Dis 212: S37-39. 